Vidya Wertta Volume 3 Nomor 1 Tahun 2020

p-ISSN 0852-7776-e-ISSN 2655-7282

https://ejournal.unhi.ac.id/index.php/vidyawertta

\title{
MENAKAR KEWENANGAN DAN TATA HUBUNGAN KELEMBAGAAN ANTARA MAJELIS DESA ADAT DENGAN DESA ADAT DI BALI
}

\author{
I Putu Sastra Wibawa, I Wayan Martha, I Komang Dedi Diana \\ sastra@unhi.ac.id, marthabadung@gmail.com dedidiana@unhi.ac.id
}

Universitas Hindu Indonesia Denpasar

\begin{abstract}
ABSTRAK
Terdapat pemberitaan bahwa Majelis Desa Adat dapat menjatuhkan sanksi kepada desa adat dalam bentuk sanksi administrasi, baik terkait surat menyurat, tidak menerima undangan rapat dan usulan kepada Gubernur untuk tidak mendapatkan bantuan pembinaan desa adat sejumlah Rp. 300 Juta jika tidak mendukung program pemerintah Provinsi khususnya terkait dengan penanganan Covid-19. Berdasarkan uraian tersebut terdapat beberapa pertanyaan yang dapat diajukan, antara lain, 1) Bagaimanakah pengaturan kewenangan dari Majelis Desa Adat di Bali dan 2) Bagaimanakah tata hubungan kelembagaan antara Majelis Desa Adat dengan desa adat di Bali. Penelitian ini termasuk penelitian hukum normatif dengan menggunakan pendekatan perundang-undangan dan pendekatan konsep. Analisa dilakukan terhadap bahan hukum primer dan bahan hukum sekunder dengan analisis deskriptif. Perda Desa Adat di Bali tidak satu pun pasal yang memberikan payung hukum Majelis Desa Adat dapat memberikan sanksi kepada desa adat Secara umum tugas Majelis Desa Adat adalah mengayomi, membina, dan mengembangkan adat istiadat yang ada di Desa Adat. Usulan pemberian sanksi kepada desa adat oleh Majelis Desa Adat jika itu terjadi akan muncul kesewenang-wenangan atau disebut sebagai tindakan sewenang-wenang atau dalam bahasa administrasi negara disebut sebagai abuse de droit atau bahkan dapat disebut terjadi pelanggaran terhadap asas kepastian hukum, Tata hubungan antara desa adat dengan Majelis Desa Adat setidaknya ada 3 (tiga) tata hubungan yang dapat dilakukan yakni, otoritatif, koordinatif; dan/atau konsultatif. Sehingga tidak ada pengaturan hubungan secara hierarki antara desa adat dengan Majelis Desa Adat.
\end{abstract}

Kata kunci: menakar, kewenangan, majelis desa adat

\begin{abstract}
There was a report that the Customary Village Assembly could impose sanctions on customary villages in the form of administrative sanctions, both related to correspondence, not accepting meeting invitations and proposals to the Governor not to receive assistance in fostering traditional villages in the amount of Rp. 300 Million if it does not support the Provincial Government's program specifically
\end{abstract}


related to the handling of Covid-19. Based on the description, there are several questions that can be asked, among others, 1) How is the authority arrangement of the Customary Village Assembly in Bali and 2) What is the institutional relationship between the Customary Village Assembly and customary villages in Bali. This research includes normative legal research using the statutory approach and the concept approach. Analysis was conducted on primary and secondary legal materials with descriptive analysis. Perda Desa Adat in Bali, not a single article that provides a legal umbrella for the Adat Village Council can impose sanctions on traditional villages. In general, the task of the Adat Village Council is to protect, foster, and develop the customs in the Adat Village. Proposal of sanction to traditional villages by the Adat Village Council if that happens will arise arbitrariness or referred to as an arbitrary act or in the language of the state administration referred to as abuse de droit or it can even be called a violation of the principle of legal certainty. adat with the Customary Village Assembly there are at least 3 (three) governance arrangements that can be carried out namely, authoritative, coordinative; and / or consultative. So there is no hierarchical relationship between customary villages and the Customary Village Assembly.

\section{PENDAHULUAN}

Pada media online https://bali.tribunnews.com/ tanggal 10 Mei 2020 dan di posting pada Pukul 15.27 WITA dengan judul berita Majelis Desa Adat (MDA) Bali Bakal Berikan Sanksi Bagi Desa Adat yang Tak Penuhi Protokol Kesehatan Penanganan Covid-19. Diberitakan pada media tersebut:

Bendesa Agung MDA Bali Ida Panglingsir Agung Putra Sukahet mengatakan, sanksi administratif yang diberikan, yakni tidak dilayani dalam surat menyurat, tidak mendapatkan undangan dan dedauhan hingga tidak diberitahu mengenai berbagai informasi yang diedarkan oleh MDA Bali. Sanksi itu diberikan sampai desa adat yang bersangkutan memiliki kesadaran dan melakukan perubahan dalam penanganan protokol kesehatan Covid-19. "Sanksi itu sudah sangat sulit buat mereka. Ini sudah sebuah ketegasan," kata Agung Sukahet saat dihubungi Tribun Bali melalui sambungan telepon, Minggu (4/5/2020) siang. Bukan hanya memberikan sanksi administratif, bila desa adat tetap membandel maka MDA Bali juga akan mengusulkan kepada Pemprov Bali supaya pemberian bantuan Rp 300 juta ditunda hingga desa adat bersangkutan merasa sadar. "Misalnya ada desa adat yang membangkang yang tidak mau melakukan program pemerintah, nah ini tetap ada sanksi. Itu terserah Pak Gubernur," jelasnya. Agung Sukahet mengatakan, jika misalnya nanti ada desa adat yang membangkang maka sanksi akan diberikan berdasarkan paruman Sabha Kerta MDA Bali. Paruman Sabha Kerta ada berbagai tahapan dan melibatkan seluruh prajuru MDA di tingkat provinsi dan Bendesa Madya MDA dari kabupaten dan kota se-Bali.

Akibat pemberitaan tersebut mendapat tanggapan yang beragam dari masyarakat pada umumnya di Bali. Tanggapan yang mengarah pada ketidaksetujuan terhadap pernyataan dari Bendesa Agung MDA yang akan

\section{7}

\section{VIDYA WERTTA}

Vol. 3 Nomor 1, April 2020 
memberikan sanksi kepada desa adat yang tidak mengindahkan program pemerintah dalam hal penanganan Covid-19, baik sanksi administratif berupa tidak dilayani dalam kegiatan surat menyurat, menerima undangan rapat/ dedauhan, dan sanksi bahwa desa adat yang bersangkutan diusulkan oleh MDA kepada Gubernur Bali untuk tidak mendapatkan dana bantuan Rp, 300.000.000.

Berdasarkan uraian tersebut di atas terdapat beberapa pertanyaan yang dapat diajukan, antara lain, 1) Bagaimanakah pengaturan kewenangan dari Majelis Desa Adat di Bali dan 2) Bagaimanakah tata hubungan kelembagaan antara Majelis Desa Adat dengan desa adat di Bali. Penelitian ini termasuk penelitian hukum normatif dengan menggunakan pendekatan perundang-undangan dan pendekatan konsep. Analisa dilakukan terhadap bahan hukum primer dan bahan hukum sekunder dengan analisis deskriptif.

\section{PEMBAHASAN \\ 2.1 Pengaturan Kewenangan Majelis Desa Adat di Bali}

Pengaturan kewenangan Majelis Adat di Bali secara formal di atur dalam Peraturan Daerah Provinsi Bali Nomor 4 Tahun 2019 tentang Desa Adat (selanjutnya ditulis Perda Desa Adat) yang telah Ditetapkan di Denpasar pada tanggal 28 Mei 2019 oleh Gubernur Bali dan Diundangkan di Denpasar pada tanggal 28 Mei 2019 Sekretaris Daerah Provinsi Bali. Dicantumkan dalam Lembaran Daerah Provinsi Bali Tahun 2019 Nomor 4 Noreg Peraturan Daerah Provinsi Bali: (4-131/2019) dan Tambahan Lembaran Daerah Provinsi Bali Nomor 4.

Menurut Ateng Syafrudin (2000: 22) kewenangan merupakan suatu kekuasaan yang bersifat formal yang diberikan oleh perundang-undangan dan wewenang diartikan sebagai bagian tertentu dari kewenangan. Ini berarti bahwa kewenangan adalah kekuasaan sah (legal) yang diberikan oleh undang-undang dan wewenang adalah suatu spesifikasi dari kewenangan, artinya subjek hukum yang diberikan kewenangan oleh undang-undang maka ia berwenang untuk melakukan sesuatu yang tersebut dalam kewenangannya itu. Meminjam pendapat Ateng Syafrudin tersebut Majelis Desa Adat dianggap memiliki kewenangan jika terdapat peraturan perundang-undangan yang mengatur kewenangannya secara formal.

Selanjutnya, terkait dengan kewenangan dalam kekuasaan hukum di suatu pemerintahan Max Weber (2008: 32) menyatakan pendapatnya bahwa "in legal authority, legitimacy is based on a belief in reason, and laws are obeyed because they have been enacted by proper procedures". (terjemahan bebas: dalam kewenangan hukum, keabsahan didasarkan pada alasan keyakinan dan hukum dipatuhi karena telah diberlakukan dengan prosedur yang tepat). Berdasarkan pendapat Max Webber tersebut kewenangan Majelis Desa Adat dianggap ada jika ada aturan hukum yang mengatur, inilah yang disebut sebagai kewenangan secara hukum.

Kewenangan dapat dikatakan sah apabila dilandasi oleh ketentuan hkum yang ada. Dengan demikian, subjek hukum dalam mengeluarkan keputusan didukung oleh sumber kewenangan. Berkaitan dengan hal tersebut, Stroink (2006: 219) berpendapat bahwa kewenangan organ (institusi) pemerintah adalah suatu 
kewenangan yang dikuatkan oleh hukum positif guna mengatur dan mempertahankannya. Tanpa kewenangan tidak dapat dikeluarkan suatu keputusan yuridis yang benar.

Kewenangan jika dilihat dari sumbernya dapat dibagi menjadi 3 (tiga) yaitu secara atribusi, delegasi maupun mandat. Menurut HR. Ridwan (2006: 105), suatu atribusi menunjuk pada kewenangan yang asli atas dasar konstitusi. Pada kewenangan delegasi, harus ditegaskan suatu penyerahan wewenang kepada organ pemerintahan yang lain. Sedangkan kewenangan mandat tidak terjadi penyerahan apapun dalam arti pemberian wewenang, akan tetapi yang diberi mandat bertindak atas nama pemberi mandat. Dalam pemberian mandat, pejabat yang diberi mandat menunjuk pejabat lain untuk bertindak atas nama mandator (pemberi mandat). Mandat diberikan oleh organ negara kepada orang lain untuk menjalankan kewenangannya berdasarkan ijin dari Negara atau Pemerintah dan bertindak atas namanya. Selain itu, mandat juga dapat diartikan sebagai suatu penyerahan wewenang kepada bawahan. Penyerahan itu bermaksud memberi wewenang kepada bawahan untuk membuat keputusan atas nama pejabat yang wewenang yang memberi mandat.

Secara formal pasal 1 angka 24 Perda Desa Adat di Bali menyatakan bahwa Majelis Desa Adat adalah persatuan (pasikian) Desa Adat di tingkat Provinsi, Kabupaten/Kota, dan Kecamatan secara berjenjang yang memiliki tugas dan kewenangan di bidang pengamalan adat istiadat yang bersumber dari agama Hindu serta kearifan lokal dan berfungsi memberikan nasihat, pertimbangan, pembinaan, penafsiran, dan keputusan bidang adat, tradisi, budaya, sosial religius, kearifan lokal, hukum adat dan ekonomi adat. Unsur-unsur dari Majelis Desa Adat dari pengaturan pasal 1 angka 24 tersebut, antara lain:

1. Merupakan persatuan (pasikian) Desa Adat di tingkat Provinsi, Kabupaten/Kota, dan Kecamatan secara berjenjang.

2. Memiliki tugas dan kewenangan di bidang pengamalan adat istiadat yang bersumber dari agama Hindu serta kearifan lokal.

3. Berfungsi memberikan nasihat, pertimbangan, pembinaan, penafsiran, dan keputusan bidang adat, tradisi, budaya, sosial religius, kearifan lokal, hukum adat dan ekonomi adat.

Dari sisi fungsinya, Majelis Desa Adat memberikan nasihat, pertimbangan, pembinaan, penafsiran dan keputusan. Muncul pertanyaan apakah memberikan pembinaan tersebut juga termasuk pemberian sanksi kepada desa adat yang tidak menjalankan program pemerintah Provinsi Bali.

Secara umum terdapat beberapa pasal yang mengatur tentang kewenangan yang diberikan secara hukum secara atribusi oleh Perda Desa Adat di Bali kepada Majelis Desa Adat dalam menjalankan tugas, kewenangan dan fungsinya tersebut. Pada pasal 11 Perda Desa Adat di Bali mengatur kewenangan bahwa Majelis Desa Adat Kabupaten/ Kota menerima laporan kesepakatan perubahan status hak dan fungsi atas tanah desa adat yang telah melalui paruman desa adat/Banjar Adat bersangkutan. Kewenangan Majelis Desa Adat di Bali dapat melakukan penyelesaian perkara adat yang tidak dapat diselesaikan oleh Kertha Desa Adat serta para pihak sesuai tingkatannya, sesuai dengan ketentuan pasal 37 ayat (4) Perda Desa Adat di Bali. Tugas dan kewenangan dari Majelis Desa Adat tingkat 
Provinsi menetapkan tuntunan sasana pacalang sesuai ketentuan pasal 47 ayat (7). Kemudian pasal 52 mengatur kewenangan Majelis Desa Adat di Bali mengatur pembentukan Lembaga Adat sesuai tingkatannya.

Kedudukan dan pembentukan Majelis Desa Adat di atur dalam pasal 74 secara singkat menyatakan bahwa Majelis Desa Adat berkedudukan di Ibu Kota Provinsi, Ibu Kota Kabupaten/Kota atau Kecamatan sesuai dengan tingkatannya. Majelis Desa Adat di Bali dibentuk melalui Paruman sesuai dengan tingkatannya dan pengurusnya dipilih dari peserta paruman sesuai dengan tingkatannya.

Merujuk teori kewenangan, bahwa kewenangan secara hukum yang dimiliki Majelis Desa Adat terkait tugas dan wewenang secara spesifik sebagai landasan kewenangan atribusinya di atur dalam pasal 76 ayat (1) yang menyatakan bahwa tugas Majelis Desa Adat, antara lain:

a) mengayomi, membina, dan mengembangkan adat istiadat;

b) memberikan saran, usul, dan pendapat/pertimbangan mengenai masalahmasalah adat dan kearifan lokal kepada Pemerintah Daerah serta berbagai pihak, baik perseorangan, kelompok, maupun lembaga;

c) melaksanakan setiap keputusan paruman dan pasamuhan;

d) mendampingi Desa Adat dalam penyuratan awig-awig dan pararem; dan

e) melaksanakan penyuluhan adat istiadat, tradisi, budaya, dan kearifan lokal masyarakat Bali secara menyeluruh.

Sedangkan, terkait dengan kewenangannya, secara hukum Majelis Desa Adat tingkat Provinsi mempunyai wewenang, antara lain:

a) menemukan, merumuskan, dan menetapkan kesatuan tafsir terkait dengan adat-istiadat dan Hukum Adat Bali;

b) membentuk organisasi lembaga adat

c) menyusun dan menetapkan ketentuan adat terkait dengan tata kelola kelembagaan dan manajemen utsaha adat;

d) memusyawarahkan masalah-masalah adat dan budaya Bali untuk melindungi kepentingan desa adat;

e) menyelesaikan perkara adat/wicara secara bertingkat yang tidak dapat diselesaikan pada tingkat Majelis Desa Adat tingkat Kecamatan;

f) memberikan pertimbangan berdasarkan nilai-nilai adat, tradisi, budaya, dan kearifan lokal masyarakat Bali terhadap setiap rencana pembangunan yang dilaksanakan di wewidangan lintas desa adat;

g) memberikan keputusan berdasarkan nilai-nilai adat, tradisi, budaya dan kearifan lokal masyarakat Bali terhadap dugaan pelanggaran yang dilakukan oleh prajuru desa adat; dan

h) memberikan keputusan berdasarkan nilai-nilai adat, tradisi, budaya, dan kearifan lokal masyarakat Bali terhadap dugaan pelanggaran larangan.

Berdasarkan ketentuan pasal 77 tugas dan wewenang Majelis Desa Adat tingkat Provinsi berlaku mutatis mutandis bagi Majelis Desa Adat tingkat Kabupaten/Kota. Menurut Black's Law Dictionary Seventh Edition, mutatis mutandis berarti 'All necessary changes having been made; with the necessary changes $<$ what was said regarding the first contract applies mutatis mutandis to all the later ones'. Maka tugas dan wewenang Majelis Desa Adat tingkat Provinsi 
berlaku sama bagi Majelis Desa Adat tingkat Kabupaten/Kota, namun terdapat perbedaan tingkatan saja.

Berbeda dengan tugas dan wewenang Majelis Desa Adat tingkat Provinsi yang berlaku mutatis mutandis bagi Majelis Desa Adat tingkat Kabupaten/Kota. Tugas dan kewenangan Majelis Desa Adat di Bali di tingkat Kecamatan di atur secara rinci pada pasal 78 ayat (1), yang menyatakan tugas Majelis Desa Adat tingkat Kecamatan antara lain:

a) memusyawarahkan masalah-masalah adat dan budaya Bali untuk melindungi kepentingan Desa Adat di tingkat Kecamatan;

b) menyelesaikan perkara adat/wicara secara bertingkat yang tidak dapat diselesaikan pada tingkat Desa Adat; dan

c) memberikan pertimbangan berdasarkan nilai-nilai adat, tradisi, budaya, dan kearifan lokal masyarakat Bali terhadap setiap rencana pembangunan yang dilaksanakan di wewidangan lintas Desa Adat.

Sedangkan kewenangan Majelis Desa Adat tingkat Kecamatan di atur dalam pasal 78 ayat (2) menyatakan bahwa Majelis Desa Adat mempunyai wewenang:

a) melakukan mediasi sebagai bentuk penyelesaian perkara adat/wicara yang tidak dapat diselesaikan di tingkat Desa Adat; dan

b) melakukan koordinasi Desa Adat di tingkat Kecamatan.

Sehingga berdasarkan hal tersebut di atas, terkait dengan tugas dan kewenangan Majelis Desa Adat secara hukum menurut Perda Desa Adat di Bali tidak satu pun pasal yang memberikan payung hukum Majelis Desa Adat dapat memberikan sanksi kepada desa adat dalam bentuk sanksi administrasi, baik terkait surat menyurat, tidak menerima undangan rapat dan usulan kepada Gubernur untuk tidak mendapatkan bantuan pembinaan desa adat sejumlah Rp. 300 Juta jika tidak mendukung program pemerintah Provinsi khususnya terkait dengan penanganan Covid-19. Secara umum tugas Majelis Desa Adat adalah mengayomi, membina, dan mengembangkan adat istiadat yang ada di Desa Adat.

Terkait dengan pengambilan keputusan pun Majelis Desa Adat sifatnya berjenjang, dan tidak langsung dilakukan eksekusi oleh Bendesa Adat Majelis Desa Adat. Hal tersebut telah di atur dalam ketentuan pasal 79 ayat (1) Perda Desa Adat yang menyatakan bahwa Keputusan Majelis Desa Adat tingkat Kabupaten/Kota dalam menyelesaikan perkara adat atau wicara dapat diajukan keberatan kepada Majelis Desa Adat tingkat Provinsi untuk mendapat keputusan. Selanjutnya pada pasal 79 ayat (2) menyatakan bahwa Keputusan Majelis Desa Adat tingkat Provinsi bersifat final dan mempunyai kekuatan hukum mengikat. Ketentuan ini menguatkan ketentuan pasal 73 ayat (3) yang menyatakan bahwa Pengambilan keputusan Majelis Desa Adat dilakukan dalam paruman dan pasamuhan sesuai dengan tingkatannya. Maka, jika kita telusuri bahwa bantuan dana pembinaan kepada desa adat merupakan kewajiban dari pemerintah daerah untuk mengalokasikan anggarannya.

Secara umum, usulan pemberian sanksi kepada desa adat oleh Majelis Desa Adat jika itu terjadi akan muncul kesewenang-wenangan atau disebut sebagai tindakan sewenang-wenang atau dalam bahasa administrasi negara disebut sebagai abuse de droit, artinya bahwa tindakan yang tidak sesuai dengan 
tujuan yang ditentukan dalam peraturan perundang-undangan. Atau bahkan dapat disebut terjadi pelanggaran terhadap asas kepastian hukum, karena pemberian sanksi kepada desa adat oleh Majelis Desa Adat belum ada aturannya.

\subsection{Tata Hubungan Desa Adat dengan Majelis Desa Adat}

Pengakuan negara terhadap keberadaan desa adat di Bali di atur dalam Peraturan Daerah Provinsi Bali Nomor 4 Tahun 2019 tentang Desa Adat. Pada peraturan daerah tersebut secara formal pengertian desa adat di atur dalam pasal 1 angka 8 yang menyatakan bahwa desa adat adalah kesatuan masyarakat hukum adat di Bali yang memiliki wilayah, kedudukan, susunan asli, hak-hak tradisional, harta kekayaan sendiri, tradisi, tata krama pergaulan hidup masyarakat secara turun temurun dalam ikatan tempat suci (kahyangan tiga atau kahyangan desa), tugas dan kewenangan serta hak mengatur dan mengurus rumah tangganya sendiri. Berdasarkan ketentuan tersebut terdapat unsur-unsur dalam desa adat di Bali, antara lain:

1. Merupakan suatu kesatuan masyarakat hukum adat di Bali. Makna kesatuan masyarakat hukum adat adalah suatu masyarakat yang tergabung dalam suatu kesatuan sistem hukum yang didasari atas hak kebersamaan.

2. Memiliki wilayah, artinya setiap desa adat di Bali dapat dikatakan sebagai desa adat jika memiliki wilayah sendiri dengan batas-batas tertentu baik batas fisik maupun batas alam.

3. Kedudukan, artinya desa adat memiliki kedudukan hukum yang jelas sebagai suatu subyek hukum yang dapat melakukan perbuatan hukum atas nama desa adat sendiri.

4. Susunan asli, artinya desa adat memiliki susunan asli baik dari sistem pemerintahan, sistem ekonomi, dll yang telah dilakukan secara turun temurun dan belum terpengaruh oleh budaya luar.

5. Hak-hak tradisional, artinya desa adat memiliki hak yang melekat secara tradisional pada desa adat tersebut, misalnya hak pengelolaan hutan adat, hak pengelolaan laut, hak atas pengelolaan tanah secara tradisional, dll.

6. Harta kekayaan sendiri, artinya desa adat memiliki harta kekayaan baik kekayaan alam, benda maupun kekayaan lainnya yang dikuasai secara komunal oleh desa adat untuk kebutuhan bersama masyarakat adat.

7. Tradisi, artinya desa adat memiliki kebiasaan yang secara turun temurun diwarisi dan dilestarikan baik dari sisi adat, seni dan budaya.

8. Tata krama pergaulan hidup masyarakat secara turun temurun dalam ikatan tempat suci (kahyangan tiga atau kahyangan desa), artinya setiap desa adat terdapat tempat suci yang disebut sebagai kahyangan desa sebagai bukti ikatan bersama.

9. Tugas dan kewenangan serta hak mengatur dan mengurus rumah tangganya sendiri, artinya desa adat memiliki kewenangan untuk mengatur rumah tangganya sendiri termasuk juga mengeluarkan aturan sendiri dalam mengatur wilayahnya.

Secara hukum dan praktik dilapangan desa adat di Bali memiliki otonomi dalam mengatur dan mengurus rumah tangganya sendiri. Namun demikian, desa adat dalam menjalankan tugas dan kewenangannya tidak dapat berjalan sendiri 
perlu melakukan hubungan kelembagaan dengan lembaga lainnya, salah satunya dengan Majelis Desa Adat. Pasal 81 ayat (1) menyatakan bahwa dalam penyelenggaraan pemerintahan, desa adat dapat melakukan tata hubungan dengan berbagai pihak. Selanjutnya pada ayat (2) menyatakan bahwa pelaksanaan tata hubungan desa adat dapat bersifat: a). otoritatif; b). koordinatif; dan/atau c). konsultatif.

Pada penjelasan pasal 81 Ayat (1) yang dimaksud dengan berbagai pihak adalah seperti : a). Pemerintah; b). Pemerintah Provinsi; c). Pemerintah Kabupaten/Kota; d). Lembaga umat Hindu; e). Majelis Desa Adat; f). Desa Adat lain; g). Desa Dinas atau Kelurahan; h). Subak atau Subak Abian; i). swasta; j). lembaga swadaya masyarakat; k). organisasi kemasyarakatan; l). lembaga pendidikan dan kebudayaan. Artinya desa adat dapat melakukan tata hubungan salah satunya dengan Majelis Desa Adat.

Penjelasan pasal 81 ayat (2) Huruf a menyatakan bahwa yang dimaksud dengan hubungan otoritatif adalah hubungan desa adat dengan berbagai pihak yang didasarkan pada kewenangan desa adat untuk melakukan verifikasi dan validasi bahwa suatu kegiatan di wewidangan desa adat telah sesuai dengan awigawig, pararem, dan/atau kebijakan desa adat. Kemudian pada Huruf b menyatakan bahwa yang dimaksud dengan hubungan koordinatif adalah hubungan antara desa adat dengan berbagai pihak yang masing-masing pihak mempunyai kedudukan sejajar untuk menyelaraskan kebijakan atau penyelenggaraan suatu kegiatan yang berkaitan dengan kepentingan desa adat. Selanjutnya pada Huruf c menyatakan bahwa yang dimaksud dengan hubungan konsultatif adalah hubungan antara Desa Adat dengan berbagai pihak untuk pertukaran pikiran guna mendapatkan saran atau nasihat yang sebaik-baiknya untuk pemecahan masalah. Sehingga berdasarkan tata hubungan tersebut, antara desa adat dengan Majelis Desa Adat setidaknya ada 3 (tiga) tata hubungan yang dapat dilakukan yakni, otoritatif, koordinatif; dan/atau konsultatif. Sehingga tidak ada pengaturan hubungan secara hierarki antara desa adat dengan Majelis Desa Adat, setidaknya juga mengacu bahwa Majelis Desa Adat adalah lembaga yang merupakan pasikian/ persatuan desa adat di Bali.

Tata hubungan antara desa adat dan Majelis Desa Adat yakni tata hubungan otoritatif, koordinatif; dan/atau konsultatif. Sebagi contoh dapat dilihat pada ketentuan pasal 82 Perda Desa Adat yang menyatakan bahwa desa adat dapat mengadakan kerjasama dengan desa adat lain, desa, dan/atau pihak lain. Dalam melaksanakan kerjasama tersebut desa adat berkoordinasi dengan Majelis Desa Adat sesuai tingkatannya. Kerjasama dituangkan dalam bentuk kesepakatan bersama atau perjanjian tertulis yang kemudian disampaikan kepada Majelis Desa Adat sesuai tingkatan. Tata hubungan antara desa adat dengan Majelis Desa Adat selanjutnya dapat dilihat pada ketentuan pasal 92 ayat (4) yang menyatakan bahwa rancangan pembangunan Kawasan Perdesaan Desa Adat dibahas bersama oleh Pemerintah Daerah, Majelis Desa Adat sesuai tingkatannya, Pemerintah Desa, dan Desa Adat.

Sehingga, dengan uraian di atas dengan adanya pernyataan dari Bendesa Agung Majelis Desa Adat terkait dengan desa adat dapat diberikan sanksi administrasi, seperti surat menyurat, tidak diberikan undangan rapat adat dan 
diusulkan tidak menerima bantuan dana pembinaan dari Gubernur jika tidak turut mendukung program pemerintah Provinsi dalam pencegahan Covid-19 dapat dikatakan bahwa otonomi desa adat yang berlaku di Bali setengah hati. Atau dalam pepatah dikatakan kepala di lepas ekor di pegang. Artinya desa adat tetap diberikan kewenangan untuk mengurus rumah tangganya sendiri, namun semuanya diatur dan harus tunduk dalam ketentuan hukum yang dibuat oleh pemerintah. Atau dalam teori pluralisme, disebut sebagai pluralisme hukum lemah, dimana hukum negara lebih dominan dibanding hukum adat.

\section{PENUTUP}

Adapun simpulan yang dapat disampaikan berdasarkan uraian pembahasan di atas, yakni: terkait dengan tugas dan kewenangan Majelis Desa Adat secara hukum menurut Perda Desa Adat di Bali tidak satu pun pasal yang memberikan payung hukum Majelis Desa Adat dapat memberikan sanksi kepada desa adat dalam bentuk sanksi administrasi, baik terkait surat menyurat, tidak menerima undangan rapat dan usulan kepada Gubernur untuk tidak mendapatkan bantuan pembinaan desa adat sejumlah Rp. 300 Juta jika tidak mendukung program pemerintah Provinsi khususnya terkait dengan penanganan Covid-19. Secara umum tugas Majelis Desa Adat adalah mengayomi, membina, dan mengembangkan adat istiadat yang ada di Desa Adat. usulan pemberian sanksi kepada desa adat oleh Majelis Desa Adat jika itu terjadi akan muncul kesewenang-wenangan atau disebut sebagai tindakan sewenang-wenang atau dalam bahasa administrasi negara disebut sebagai abuse de droit, artinya bahwa tindakan yang tidak sesuai dengan tujuan yang ditentukan dalam peraturan perundang-undangan. Atau bahkan dapat disebut terjadi pelanggaran terhadap asas kepastian hukum, karena pemberian sanksi kepada desa adat oleh Majelis Desa Adat belum ada aturannya. Tata hubungan tersebut, antara desa adat dengan Majelis Desa Adat setidaknya ada 3 (tiga) tata hubungan yang dapat dilakukan yakni, otoritatif, koordinatif; dan/atau konsultatif. Sehingga tidak ada pengaturan hubungan secara hierarki antara desa adat dengan Majelis Desa Adat, setidaknya juga mengacu bahwa Majelis Desa Adat adalah lembaga yang merupakan pasikian/ persatuan desa adat di Bali.

Rekomendasi yang dapat disampaikan yakni, tata hubungan antara desa adat dan Majelis Desa Adat harus segera diterbitkan Peraturan Gubernur sebagai tindak lanjut dari ketentuan pasal 81 ayat (1), (2) dan (3) Perda Desa Adat di Bali, dan agar secara kelembagaan Majelis Desa Adat baik secara kelembagaan maupun bertindak atas nama prajuru tetap berada pada ranah mengayomi, membina, dan mengembangkan adat istiadat yang ada di desa adat.

\section{DAFTAR PUSTAKA}

Darmayanti, Arindi Ayudia, 2016, Kekuatan Mengikat Akta Konsen Roya Yang Dibuat Oleh Notaris, Tesis, Program Magister Kenotariatan, Program Pascasarjana Universitas Udayana, Denpasar.

Ridwan, HR., 2006, Hukum Administrasi Negara, PT. Raja Grafindo Persada, Jakarta. 
Syafrudin, Ateng, 2000, Menuju Penyelenggaraan Pemerintahan Negara Yang Bersih dan Bertanggungjawab, Jurnal Pro Justisia Edisi IV Tahun 2000, Universitas Prahyangan, Bandung.

Thalib, Abdul Rasyid, 2006, Wewenang Mahkamah Konstitusi dan Implikasinya dalam Sistem Ketatanegaraan Republik Indonesia, Citra Aditya Bakti, Bandung.

Weber, Max, 2008, Matering Public Administration, Washington, CQ Press, Second Edition.

Peraturan Daerah Provinsi Bali Nomor 4 Tahun 2019 tentang Desa Adat (Lembaran Daerah Provinsi Bali Tahun 2019 Nomor 4 Noreg Peraturan Daerah Provinsi Bali: (4-131/2019) dan Tambahan Lembaran Daerah Provinsi Bali Nomor 4). 